\title{
Geology
}

\section{Intraplate extension prior to continental extrusion along the Ailao Shan-Red River shear zone}

Sun-Lin Chung, Tung-Yi Lee, Ching-Hua Lo, Pei-Ling Wang, Chin-Yu Chen, Nguyen Trong Yem, Tran Trong Hoa and Wu Genyao

Geology 1997;25;311-314

doi: 10.1130/0091-7613(1997)025<0311:IEPTCE>2.3.CO;2

Email alerting services

Subscribe

Permission request click www.gsapubs.org/cgi/alerts to receive free e-mail alerts when new articles cite this article

click www.gsapubs.org/subscriptions/ to subscribe to Geology

click http://www.geosociety.org/pubs/copyrt.htm\#gsa to contact GSA

Copyright not claimed on content prepared wholly by U.S. government employees within scope of their employment. Individual scientists are hereby granted permission, without fees or further requests to GSA, to use a single figure, a single table, and/or a brief paragraph of text in subsequent works and to make unlimited copies of items in GSA's journals for noncommercial use in classrooms to further education and science. This file may not be posted to any Web site, but authors may post the abstracts only of their articles on their own or their organization's Web site providing the posting includes a reference to the article's full citation. GSA provides this and other forums for the presentation of diverse opinions and positions by scientists worldwide, regardless of their race, citizenship, gender, religion, or political viewpoint. Opinions presented in this publication do not reflect official positions of the Society.

\section{Notes}

Geological Society of America

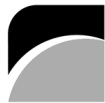

THE

GEOLOGICAL

SOCIETY

OF AMERICA 


\title{
Intraplate extension prior to continental extrusion along the Ailao Shan-Red River shear zone
}

\author{
Sun-Lin Chung* Department of Geology, National Taiwan University, Taipei 106-17, Taiwan \\ Tung-Yi Lee Department of Earth Sciences, National Taiwan Normal University, Taipei, Taiwan \\ Ching-Hua Lo 7 - Department of Geology, National Taiwan University, Taipei 106-17, Taiwan \\ Chin-Yu Chen Department of Earth Sciences, National Taiwan Normal University, Taipei, Taiwan \\ Nguyen Trong Yem \\ Tran Trong Hoa - Institute of Geological Sciences, National Center for Natural Sciences and Technology, Hanoi, Vietnam \\ Wu Genyao Institute of Geology, Chinese Academy of Sciences, Beijing, China
}

\begin{abstract}
Left-lateral movement of the Ailao Shan-Red River shear zone lends support to the hypothesis of continental extrusion resulting from the collision of India with Asia. Our new observations from northwestern Yunnan, China, and northwestern Vietnam on different sides of the shear zone demonstrate that the sinistral offset was $\sim 600 \mathrm{~km}$ according to correlations of Permian-Triassic flood basalt successions and late Paleogene highly potassic mafic magmas. We conclude that the shear was propagating on the South China continental margin and does not correspond to a suture between South China and Indochina. Furthermore, the highly potassic magmas were emplaced from ca. 40 to $30 \mathrm{Ma}$, before the shear movement, which was caused by the late Oligocene to early Miocene (ca. 27-22 Ma) extrusion activity. This suggests that a late Eocene to early Oligocene intraplate extension, possibly induced by delamination of thickened continental lithosphere, took place in northwestern Yunnan (or eastern Tibet) as a response to the India-Asia collision. This extension, and sea-floor spreading of the South China Sea that began ca. $30 \mathrm{Ma}$, could have accounted for the initiation of the Ailao Shan-Red River shear zone.
\end{abstract}

\section{INTRODUCTION}

Insight on the processes of continental collision and resultant effects has been obtained by studying the Himalayan mountain belt and surrounding regions (cf. Tapponnier et al., 1986; Harrison et al., 1992b; Molnar et al., 1993). Since the proposition of the extrusion model by Tapponnier et al. (1982), there has been considerable debate on whether crustal thickening or eastward displacement has been more significant in the Cenozoic geotectonic evolution of Asia (e.g., Tapponnier et al., 1990; Houseman and England, 1993; Leloup et al., 1995). Crustal thickening in and around the Tibetan Plateau is a direct consequence of the collision between Indian and Asian continents; it resulted in the Tibetan uplift, which in turn intensified the Asian monsoon and affected global atmospheric circulation (Harrison et al., 1992b; Molnar et al., 1993). However, strike-slip movement along the Ailao Shan-Red River shear zone (Fig. 1) has been widely viewed as a key process in shaping the present-day Southeast Asia and responsible for opening of the South China Sea (cf. Lee and Lawver, 1995; Leloup et al., 1995).

We report new observations along the Ailao Shan-Red River shear zone, and two types of igneous rocks on either side of the shear zone are considered as a means to refine estimates of the offset. These are the PermianTriassic Emeishan flood basalts and late Paleogene highly potassic mafic magmas from northwestern Yunnan and northwestern Vietnam. Genesis of the latter, in comparison with the late Miocene to Quaternary potassic volcanism in Tibet, the eruption of which has been attributed to an extensional setting resulting from removal of the base of thickened lithosphere (England, 1993; Turner et al., 1993, 1996), can offer important information concerning the tectonic evolution in Southeast Asia. Our major goals are to better under-

\footnotetext{
* Correspondence to Sun-Lin Chung; E-mail: sunlin@ccms.ntu.edu.tw.
}

stand the following questions. What was the magnitude of strike-slip offset of the Ailao Shan-Red River shear zone? Was it propagating along the plate boundary between South China and Indochina? Why were the late Paleogene highly potassic lavas generated? How was the collision-induced strain partitioned in terms of crustal thickening and eastward extrusion?

\section{THE AILAO SHAN-RED RIVER SHEAR ZONE}

The Ailao Shan-Red River shear zone extends through Yunnan Province, southwestern China to northern Vietnam. It is over $1000 \mathrm{~km}$ long between eastern Tibet and the Tonkin Gulf and represents the most pronounced morphologic and geologic discontinuity in Southeast Asia. The shear zone consists of high-grade metamorphic rocks, mainly of Middle Proterozoic gneisses (Fig. 1). It has often been regarded as a suture separating the South China from Indochina blocks (cf. Leloup et al., 1995) because dismembered mafic and ultramafic rocks, suggested to be ophiolitic fragments (Zhang et al., 1994), crop out south of the Ailao Shan in Paleozoic and Mesozoic formations. Whereas the shear zone corresponds to a rightlateral fault belt (Allen et al., 1984), investigations have shown that the foliated and/or mylonitic gneiss cores previously underwent a left-lateral, ductile deformation (cf. Tapponnier et al., 1990; Leloup et al., 1995). U-Pb and Ar-Ar radiometric studies on small leucogranitic bodies in the shear zone have yielded an age span of ca. 27-22 Ma (Schärer et al., 1990; 1994; Harrison et al., 1992a), indicating a mid-Tertiary sinistral shear movement. The shear subsequently ceased and was reactivated with a right-lateral motion from ca. $5 \mathrm{Ma}$ (Leloup et al., 1993). Estimates of the strike-slip magnitude of the Ailao Shan-Red River shear zone have been contentious until recently. Leloup et al. (1995) proposed a left-lateral offset of $700 \pm 200 \mathrm{~km}$, to which a few tens of kilometres of post-Miocene dextral slip should be added. However, on the basis of seismic profiles in the Tonkin Gulf, Rangin et al. (1995) argued that observed sedimentary packages can accommodate no more than $100 \mathrm{~km}$ of mid-Tertiary sinistral movement.

\section{GEOLOGIC CORRELATION}

\section{Permian-Triassic Flood Basalts}

The Emeishan Basalt represents a continental flood basalt province that comprises vast volcanic successions emplaced mainly in the western South China block during Permian-Triassic time (Huang, 1986; Chung and Jahn, 1995). It has been proposed to have resulted from a starting mantle plume from the deep mantle (Chung and Jahn, 1995). Outcrops of these volcanic rocks are dispersed within a rhomb-shaped area of $\sim 2.5 \times 10^{5} \mathrm{~km}^{2}$, block faulted since the Jurassic. The faulting also exposed associated intrusive rocks in many localities in the Emeishan province. The plume axis is suggested to have been located at the western part of the province, where the volcanic succession reaches a thickness of about $5 \mathrm{~km}$ near Dali, southeast of the Diancangshan, northwestern Yunnan (Fig. 1), and is marked by an occurrence of highly magnesian picritic flows (Chung and Jahn, 1995). According to the mantle plume hypothesis (Campbell and Griffiths, 1990), such high$\mathrm{Mg}$ primary lavas can only be generated from the central jet of a mantle 


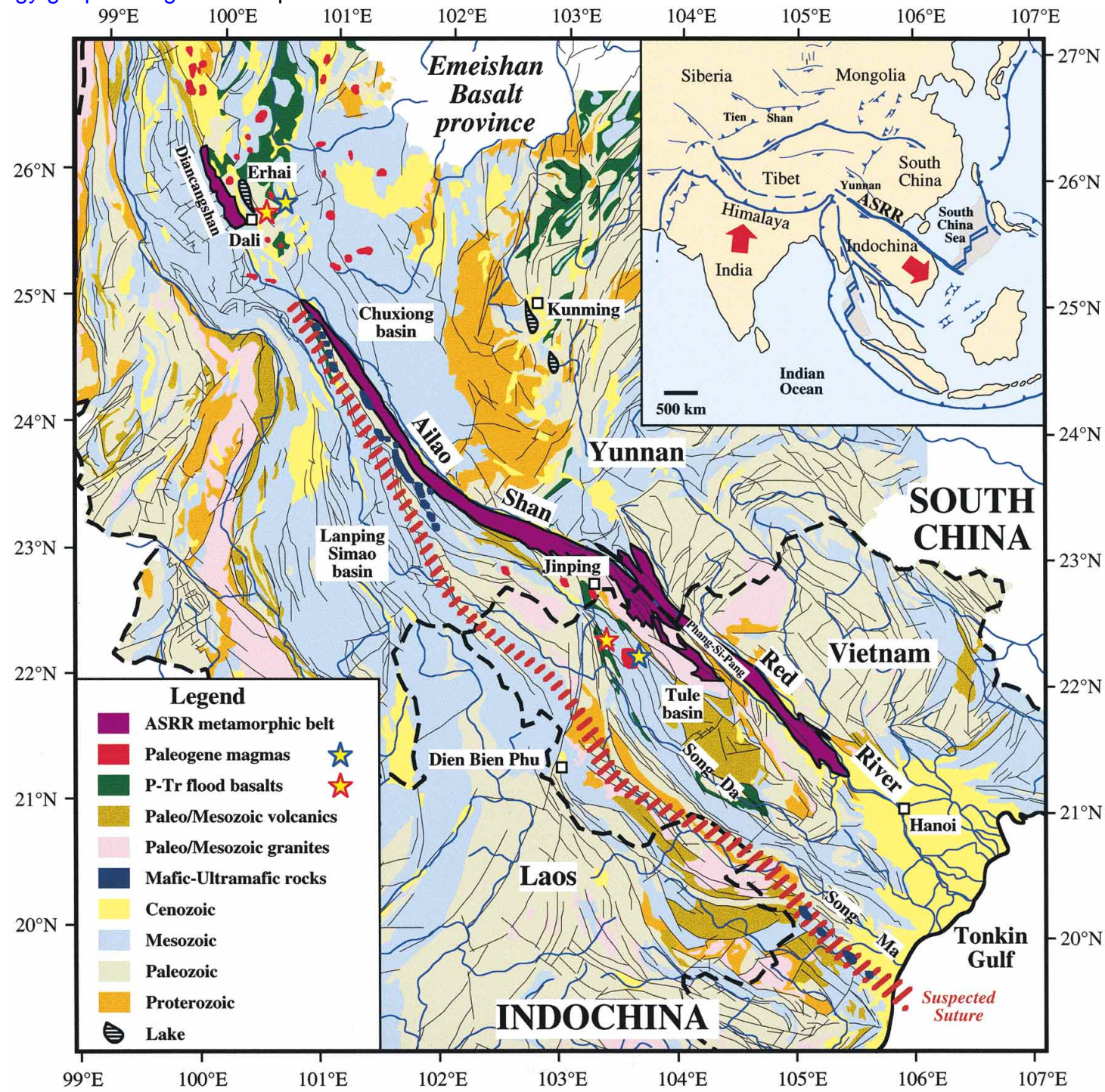

Figure 1. Simplified geologic map of Ailao Shan-Red River shear zone and adjacent regions. Modified from Bureau of Geology and Mineral Resources of Yunnan (1990) and Geologic Society of Vietnam (1988). Inset marks major Cenozoic fault systems in Asia (after Tapponnier et al., 1990). Stars in red and blue boundaries indicate locations of Permian-Triassic highly magnesian lavas and late Paleogene highly potassic mafic magmas, respectively. Pu-Sam-Cap alkaline complex, marked with blue star, is located in northern part of Tule basin, south of Phang Si-Pang mountain range. Suspected suture belt between South China and Indochina, situated south of shear zone, is shown as hatched band. Central portion of Emeishan Basalt province has been covered mainly by Mesozoic sedimentary formations in Chuxiong basin.

$99^{\circ} \mathrm{E} \quad 100^{\circ} \mathrm{E} \quad 101^{\circ} \mathrm{E}$

plume (i.e., plume axis) that has higher potential temperature and would affect an area $<150 \mathrm{~km}$ wide. The Emeishan picrite magmas have whole-rock $\mathrm{MgO}$ contents of 16-20 wt\%. They are variably enriched in the highly incompatible trace elements and depleted in the heavy rare earth elements (Fig. 2a), and are thereby interpreted as products of plume-lithosphere interaction (Chung and Jahn, 1995).

We propose a genetic link between the Emeishan Basalt and contemporaneous mafic-ultramafic rock suites in the Song Da belt, northwestern Vietnam (Fig. 1). The latter have been regarded as a komatiite-basalt association affiliated with a rift setting (Polyakov et al., 1991). However, a good stratigraphic and petrologic correlation between the western successions in the Emeishan Basalt province and a thick basaltic sequence in Jinping, near the China-Vietnam border (Fig. 1), was documented by Wu (1993). Our new data (Fig. 2a) indicate that two types of magmas can be delineated for the ultramafic rocks in the Song Da belt. One is picrite, which has a whole-rock chemistry of $\mathrm{MgO}<20 \mathrm{wt} \%$ and enriched incompatible trace elements and contains olivine as the dominant phenocryst phase, suggesting a primary or near-primary melt composition. The other is ankaramite, which has $\mathrm{MgO}$ as much as $27 \mathrm{wt} \%$ and clinopyroxene as the major mineral constituent, implying a cumulate origin from crystal fractionation processes. When compared with the Emeishan Basalt (Fig. 2a), these magmas show remarkably similar incompatible trace element patterns. Thus, a genetic link can be suggested.

\section{Late Paleogene High-Potassic Magmas}

Late Paleogene alkaline magmatic rocks occur in northwestern Yunnan and northwestern Vietnam (Fig. 1). They are little known by the geologic community and thus unrecognized for their geodynamic significance. The rocks include a series of small volcanic and plutonic bodies of the Ailao Shan-Red River shear zone. Those emplaced in the Haidong area (east of the Erhai Lake, northwestern Yunnan) and the Pu-Sam-Cap igneous complex (south of the Phang-Si-Pang mountain, northwestern Vietnam) are the easternmost outcrops on the north and south sides of the shear zone, respectively (Fig. 1). This occurrence also supports the notion that subsequent leftlateral displacement by the Ailao Shan-Red River shear zone occurred. The rocks in Yunnan have been studied in more detail; radiometric datings yielded a magmatic duration spanning ca. 40 to $30 \mathrm{Ma}$ (Zhang et al., 1987; Zhu et al., 1992). Volcanic rocks from the Haidong area are composed predominantly of highly potassic mafic lavas (Fig. 2b), which have high strontium and lead (i.e., ${ }^{87} \mathrm{Sr} /{ }^{86} \mathrm{Sr} \approx 0.705-0.707 ;{ }^{206} \mathrm{~Pb} /{ }^{204} \mathrm{~Pb} \approx 18.5-18.8$ ) and low neodymium $\left({ }^{143} \mathrm{Nd} /{ }^{144} \mathrm{Nd} \approx 0.5123-0.5126\right)$ isotopic ratios (Zhu et al., 1992 ), likely reflecting a lithospheric mantle source origin.

The Pu-Sam-Cap igneous complex in northwestern Vietnam also comprises a group of mafic to felsic alkaline rocks. The mafic lavas, possessing Ti-rich phlogopite as an important mineral phase, have been termed cocites (Wagner and Velde, 1986). Our Ar-Ar radiometric result for one of these cocite samples gave an integrated plateau date of $29.9 \pm 0.9$ (2s) Ma and an isochron date of $30.0 \pm 1.1 \mathrm{Ma}$ (Fig. 3). The cocites are of basaltic composition $\left(\mathrm{SiO}_{2} \approx 50 \mathrm{wt} \%\right)$ and show highly magnesian $(\mathrm{MgO}>10 \mathrm{wt} \%)$ and potassic $\left(\mathrm{K}_{2} \mathrm{O} / \mathrm{Na}_{2} \mathrm{O}>3\right)$ character. Their elemental features are almost identical to those of highly potassic mafic magmas in the Haidong area. In addition to high potassium contents, enrichments in the large ion lithophile elements (e.g., Th and $\mathrm{U}$ ) and depletions in the high field strength elements 


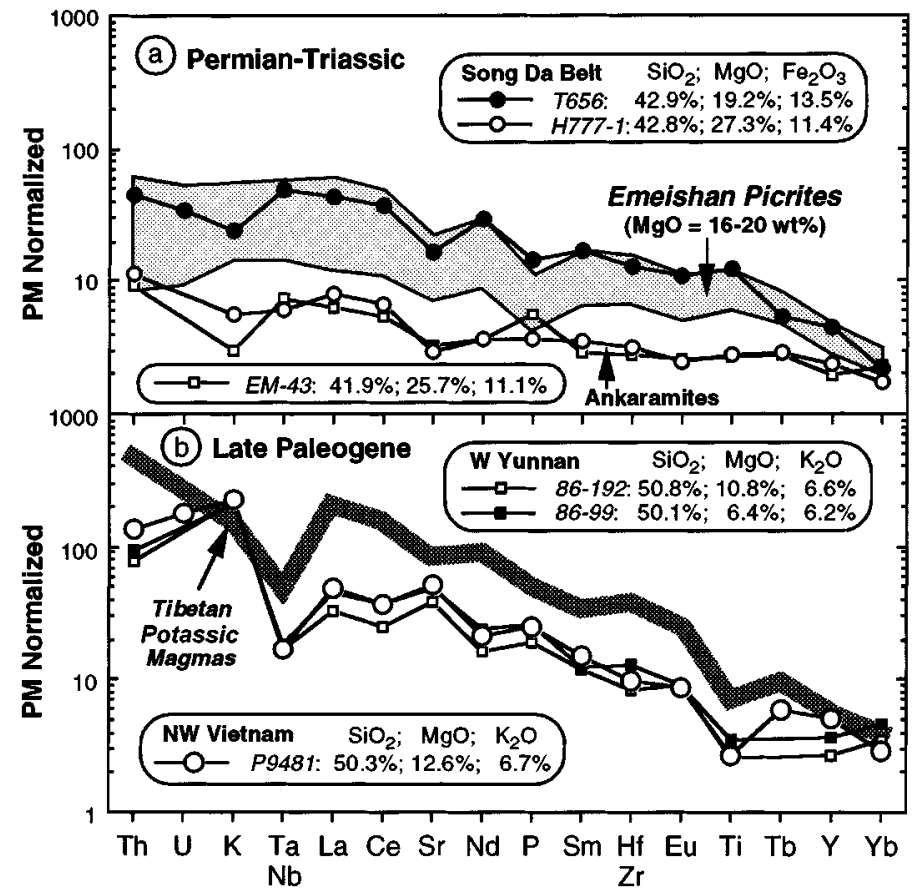

Figure 2. Primitive mantle (PM)-normalized diagrams for (a) PermianTriassic high-Mg lavas and (b) late Paleogene high-K mafic magmas in Yunnan and Vietnam. In a, samples T656 and H777-1 represent picritic and ankaramitic lavas, respectively, from Song Da belt, Vietnam. Along with picrites shown by shaded region, ankaramite flow (EM-43) from western Emeishan province near Dali is plotted. Emeishan data are from Chung and Jahn (1995). In b, remarkable match exists between mafic magmas from Haidong area (Yunnan) and Pu-Sam-Cap complex (Vietnam). Former are from Zhu et al. (1992). Additionally, mafic potassic rocks on Tibetan Plateau (Turner et al., 1996) are compared. Primitive mantle values are from Sun and McDonough (1989).

( $\mathrm{Nb}, \mathrm{Ta}$, and $\mathrm{Ti}$ ) are observed in both cases (Fig. 2b). This coherency suggests a common petrogenetic process for these two magmatic suites, most likely derived from a phlogopite-bearing lithospheric mantle source region that has been recently modified by subduction-related processes.

\section{DISCUSSION}

Recognition of the two well-correlated markers, picritic lavas of the Permian-Triassic flood basalt successions and mafic magmas of the late Paleogene alkaline rock suites, allows a consistent left-lateral offset estimate of $\sim 500 \mathrm{~km}$ (Fig. 1). If a few tens of kilometres of post-Miocene dextral motion (Allen et al., 1984; Leloup et al., 1995) are added, the mid-Tertiary sinistral displacement along the ASRR shear zone may have been $\sim 600 \mathrm{~km}$. This magmatic correlation, in addition to the Paleozoic and Mesozoic stratigraphic evidence (Fig. 1), does not support the suggestion that the shear zone corresponds to a suture that separates Indochina from South China (cf. Tapponnier et al., 1990; Leloup et al., 1995). Rather, it may be argued that shearing was propagated on the South China continental margin and the suture is located to the south of the Ailao Shan, possibly extending toward the Song Ma ophiolite belt (Fig. 1). In this sense, the Tule basin in Vietnam, comprising Upper Jurassic to Cretaceous sedimentary formations associated with abundant igneous activity (Fig. 1), represents a southern extension of the Chuxiong basin in Yunnan. The Vietnamese Song Da belt can be correlated with the late Paleozoic Panxi rift (Cong, 1988), the development of which in the western South China margin might have been associated with the plumerelated Emeishan flood volcanism and rifting of the Qiangtang block of eastern Tibet off South China (Huang et al., 1992; Chung and Jahn, 1995).

Specifically, we emphasize the importance of late Paleogene (ca. 40-30 Ma) alkaline magmatism, in particular the occurrence of highly potassic mafic lavas in northwestern Yunnan (and northwestern Vietnam), in conjunction with the Southeast Asian tectonic history following the India-Asia

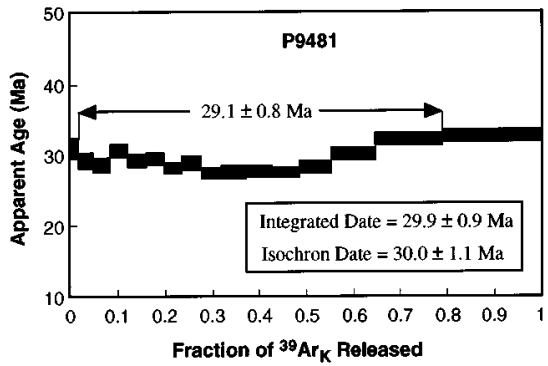

Figure 3. Ar-Ar radiometric dating spectrum for wholerock cocite sample from Pu-Sam-Cap igneous complex. Plateau date is shown between arrows, which indicate gas fraction included in this age calculation. Integrated and isochron dates are also given.

collision. It is generally accepted that generation of such potassic magmas, especially those with $\mathrm{MgO}$ contents up to $\sim 12 \mathrm{wt} \%$ (Fig. 2b), would result from a dilational rather than compressional setting (cf. Turner et al., 1996). On the Tibetan Plateau, for example, potassic volcanism since ca. $13 \mathrm{Ma}$ (Turner et al., 1993) has been ascribed to the onset of extensional deformation within the plateau. This was likely caused by removal of thickened lithosphere and resultant rapid heating of the mechanical boundary layer (England, 1993; Turner et al., 1993, 1996). Similarly, we propose that in northwestern Yunnan (or eastern Tibet) a local extensional regime occurred during late Paleogene time and perhaps accounted for the formation of late Eocene to Oligocene rifted basins east of the Diancangshan (Leloup et al., 1995). Considering the convergence of the Indian continent with Asia, which began probably as early as ca. $60 \mathrm{Ma}$ at its northeastern promontory (cf. Lee and Lawver, 1995), this extension may have been obtained if the lower part of thickened lithospheric mantle were delaminated in that region ca. $40 \mathrm{Ma}$. The removal of basal continental lithosphere and subsequent replacement by the asthenosphere could have suddenly changed the thermal structure to heat up and trigger melting of phlogopite-bearing metasomes within the upper lithospheric mantle (England, 1993; Turner et al., 1993, 1996). This interpretation is consistent with geophysical data available from northwestern Yunnan (e.g., Tan, 1987; Cong, 1988), which reveal a Moho depth of $\sim 50 \mathrm{~km}$ and total lithospheric thickness of $\sim 80 \mathrm{~km}$ in support of removal of thickened continental lithosphere.

On the basis of U-Pb and Ar-Ar dates of the leucogranitic veins (Schärer et al., 1990, 1994; Harrison et al., 1992a; Leloup et al., 1993), Leloup et al. (1995) concluded that the left-lateral movement of the Ailao Shan-Red River shear zone lasted from ca. 35 to 20-17 Ma. The onset age was established simply to reconcile the U-Pb mineral date $(35.0 \pm 0.1 \mathrm{Ma})$ for a small monzonite body in Jianchuan, north of the Diancangshan (Schärer et al., 1994). This time span was nearly coeval with that of the spreading of the South China Sea (ca. 32-15.5 Ma; Briais et al., 1993), thus strengthening the continental extrusion model, which advocates a largescale sinistral movement of Indochina relative to South China to initiate opening of the South China Sea (cf. Tapponnier et al., 1986). However, we note that the monzonite is located outside the shear zone (cf. Fig. 1 of Schärer et al., 1994) and shows chemical features that are distinct from the leucogranitic veins within the shear zone but similar to the felsic member of late Paleogene alkaline igneous rocks (Zhang et al., 1987). Our view is consistent with a point also made by Leloup et al. (1995), i.e., none of the radiometric dates on leucogranites yields ages older than 27 Ma or younger than $22 \mathrm{Ma}$. Because the Pu-Sam-Cap complex, which was emplaced ca. $30 \mathrm{Ma}$, has been transported from northwestern Yunnan to northwestern Vietnam, it is more reasonable to argue that the left-lateral shear motion was initiated between ca. 30 and $27 \mathrm{Ma}$. We suggest that the shear zone underwent a main ductile deformation from ca. 27 to $22 \mathrm{Ma}$, although brittle shearing could have continued until ca. 20-17 Ma, as implied from the cooling history analysis of gneiss cores (Leloup et al., 1995). According to a recent Cenozoic geomagnetic polarity time scale (Cande and Kent, 1992), the magnetic lineations (11 to 5C) identified for oceanic crust in the South China Sea (Taylor and Hayes, 1983; Briais et al., 1993) should correspond to about 30 to $16 \mathrm{Ma}$. Therefore, spreading of the South China Sea might have commenced earlier than the strike-slip movement of the Ailao ShanRed River shear zone and was still in progress after cessation of the latter. These age constraints are in apparent contradiction to those required by the extrusion model. It is more likely that an extensional regime existed in the 
South China continental margin prior to the onset of eastward extrusion of Indochina in the late Oligocene.

\section{CONCLUSIONS}

We report new evidence from the Ailao Shan-Red River shear zone that provides further insights on the Cenozoic tectonic evolution in Southeast Asia related to the Indian indentation. We propose that lithosphere thickening, intraplate extension, and eastward extrusion occurred as discrete deformational phases in and around the Tibetan Plateau. As a response to the collision which led to regional thickening deformation, an extensional environment was formed after the late Eocene in areas surrounding eastern Tibet. The extension, probably owing to a sudden removal of thickened lithosphere, lasted until the early Oligocene and caused emplacements of lithospheric mantle-derived potassic magmas in northwestern Yunnan. This was followed by the initiation of left-lateral displacement of the Ailao Shan-Red River shear zone, which was propagating between two weakened upper mantle domains within the South China continental margin, i.e., the extension around eastern Tibet in the west and opening of the South China Sea in the east. The sinistral shear motion was active since the latest Oligocene, and its total offset is estimated to have been $\sim 600 \mathrm{~km}$. Subsequently, as shown by studies in the Himalayas and Tibet (see Harrison et al., 1992b, for a review), a drastic shift from the extrusion-dominated back to thickening-dominated tectonics took place in the early Miocene (ca. $20 \mathrm{Ma}$ ) in the entire region. This eventually created the Tibetan Plateau, which reached the present elevation and then underwent a regional postcollision extension after late Miocene time.

\section{ACKNOWLEDGMENTS}

Supported by the National Science Council, Taiwan, Republic of China (NSC852111-M-003-011Y). We thank Dinh Van Toan, Tran Van Thang, Le Van Minh, and Hoang Huu Thanh for help with field trips in Vietnam, and Martin Flower, Greg Houseman, and Shen-su Sun for thoughtful comments.

\section{REFERENCES CITED}

Allen, C. R., Gillespie, A. R., Han, Y., Sieh, K. E., Zhang, B., and Zhu, C., 1984, Red River and associated faults, Yunnan Province, China: Quaternary geology, slip rates and seismic hazard: Geological Society of America Bulletin, v. 95, p. 686-700.

Briais, A., Patriat, P., and Tapponnier, P., 1993, Updated interpretation of magnetic anomalies and seafloor spreading stages in the South China Sea; implications for the Tertiary tectonics of SE Asia: Journal of Geophysical Research, v. 98, p. 6299-6328.

Bureau of Geology and Mineral Resources of Yunnan, 1990, Regional geology of Yunnan Province: Beijing, Geologic Press, Geologic Memoir 21, 728 p.

Campbell, I. H., and Griffiths, R. W., 1990, Implications of mantle plume structure for the evolution of flood basalts: Earth and Planetary Science Letters, v. 99, p. 79-93.

Cande, S. C., and Kent, D. V., 1992, A new geomagnetic polarity time scale for the Late Cretaceous and Cenozoic: Journal of Geophysical Research, v. 97, p. 11917-11951.

Chung, S. L., and Jahn, B. M., 1995, Plume-lithosphere interaction in generation of the Emeishan flood basalts at the Permian-Triassic boundary: Geology, v. 23, p. $889-892$.

Cong, B., ed., 1988, Formation and evolution of the Panxi paleorift: Beijing, Science Press, $424 \mathrm{p}$.

England, P., 1993, Convective removal of thermal boundary layer of thickened continental lithosphere: A brief summary of causes and consequences with special reference to the Cenozoic tectonics of the Tibetan Plateau and surrounding regions: Tectonophysics, v. 223, p. 67-73.

Geological Survey of Vietnam, 1988, Geologic map of Vietnam: Hanoi, Geological Survey of Vietnam, scale 1:500 000.

Harrison, T. M., Chen, W., Leloup, P. H., Ryerson, F. J., and Tapponnier, P., 1992a, An early Miocene transition in deformation regime within the Red River fault zone, Yunnan, and its significance for the Indo-Asian tectonics: Journal of Geophysical Research, v. 97, p. 7159-7182.

Harrison, T. M., Copland, P., Kidd, W. S. F., and Yin, A., 1992b, Raising Tibet: Science, v. 255, p. 1663-1670.

Houseman, G., and England, P., 1993, Crustal thickening versus lateral expulsion in the Indian-Asian continental collision: Journal of Geophysical Research, v. 98, p. $12233-12249$.
Huang, K. N., 1986, The petrologic and geochemical characteristics of the Emeishan Basalts from SW China and the tectonic setting of their formation [Ph.D. thesis]: Beijing, Institute of Geology, Academia Sinica, 173 p.

Huang, K. N., Opdyke, N. D., Peng, X. J., and Li, J. G., 1992, Paleomagnetic results from the Upper Permian of the eastern Qiangtang Terrane of Tibet and their tectonic implications: Earth and Planetary Science Letters, v. 111, p. 1-10.

Lee, T. Y., and Lawver, L. A., 1995, Cenozoic plate reconstruction of Southeast Asia: Tectonophysics, v. 251, p. 85-138.

Leloup, P. H., Harrison, T. M., Ryerson, F. J., Chen, W., Li, Q., Tapponnier, P., and Lacassin, R., 1993, Structural, petrological and thermal evolution of a Tertiary ductile strike-slip shear zone, Diancang Shan, Yunnan: Journal of Geophysical Research, v. 98, p. 6715-6743.

Leloup, P. H., and nine others, 1995, The Ailao Shan-Red River shear zone (Yunnan, China), Tertiary transform boundary of Indochina: Tectonophysics, v. 251, p. 3-84.

Molnar, P., England, P., and Martinod, J., 1993, Mantle dynamics, the uplift of the Tibetan Plateau, and the Indian monsoon: Review of Geophysics, v. 31, p. 357-396.

Polyakov, G. V., Balykin, P. A., Glotov, A. I., Tran, Q. H., Ngo, T. P., Hoang, H. T., and Bui, A. N., 1991, High-Mg volcanics in the Da River zone: Proceedings, Conference on Geology of Vietnam, 2nd, Hanoi, p. 247-260.

Rangin, C., Klein, M., Roques, D., Le Pichon, X., and Le Van Trong, 1995, The Red River fault system in the Tonkin Gulf, Vietnam: Tectonophysics, v. 243, p. 209-222.

Schärer, U., Tapponnier, P., Lacassin, R., Leloup, P. H., Zhong, D., and Ji, S., 1990, Intraplate tectonics in Asia: A precise age for large-scale Miocene movement along the Ailao Shan-Red River shear zone, China: Earth and Planetary Science Letters, v. 97, p. 65-77.

Schärer, U., Zhang, L. C., and Tapponnier, P., 1994, Duration of strike-slip movements in large shear zones: The Red River belt, China: Earth and Planetary Science Letters, v. 126, p. 379-397.

Sun, S.-s., and McDonough, W. F., 1989, Chemical and isotopic systematics of oceanic basalts: Implications for mantle composition and processes, in Saunders, A. D., and Norry, M. J., eds., Magmatism in the ocean basins: Geological Society [London] Special Publication 42, p. 313-345.

Tan, T. K., 1987, Geodynamics and tectonic evolution of the Panxi rift: Tectonophysics, v. 133, p. 287-304.

Tapponnier, P., Peltzer, G., Armijo, R., Le Dain, A. Y., and Cobbold, P., 1982, Propagating extrusion tectonics in Asia: New insights from simple experiments with plasticine: Geology, v. 10, p. 611-616.

Tapponnier, P., Peltzer, G., and Armijo, R., 1986, On the mechanics of the collision between India and Asia, in Coward, M. P., and Ries, A. C., eds., Collision tectonics: Geological Society [London] Special Publication 19, p. 115-157.

Tapponnier, P., and nine others, 1990, The Ailao Shan-Red River metamorphic belt: Tertiary left-lateral shear between Indochina and South China: Nature, v. 343, p. $431-437$.

Taylor, B., and Hayes, D. E., 1983, Origin and history of the South China Sea, in Hayes, D. E., ed., The tectonic and geologic evolution of Southeast Asian seas and islands, Part 2: American Geophysical Union Monograph 27, p. 23-56.

Turner, S., Hawkesworth, C. J., Liu, J., Rogers, N., Kelly, S., and van Calsteron, P., 1993, Timing of Tibetan uplift constrained by analysis of volcanic rocks: Nature, v. 364 , p. 50-53.

Turner, S., and eight others, 1996, Post-collisional, shoshonitic volcanism on the Tibetan Plateau: Implications for convective thinning of the lithosphere and the source of ocean island basalts: Journal of Petrology, v. 37, p. 45-71.

Wagner, C., and Velde, D., 1986, Lamproites in North Vietnam? A re-examination of cocites: Journal of Geology, v. 94, p. 770-776.

Wu, G. Y., 1993, Permian basalts in Lijiang and Jinping, western Yunnan: A comparative study and its geologic significance: Acta Petrologica Sinica, v. 9 (supplement), p. 63-69.

Zhang, Q., Zhou, D. J., Zhao, D. S., Huang, Z. X., Han, S., Jia, Z. Q., and Dong, J. Q., 1994, Ophiolites of the Hengduan Mountains, China: Characteristics and tectonic settings: Journal of Southeast Asian Earth Sciences, v. 9, p. 335-344.

Zhang, Y. Q., Xie, Y. W., and Tu, G. Z., 1987, Preliminary studies of the alkali-rich intrusive rocks in the Ailaoshan-Jinshajiang belt and their bearing on rift tectonics: Acta Petrologica Sinica, v. 3, p. 17-26.

Zhu, B. Q., Zhang, Y. Q., and Xie, Y. W., 1992, Nd, Sr and Pb isotope characteristics of Cenozoic ultrapotassic volcanic rocks from Haidong, Yunnan, and their implications for subcontinental mantle evolution in southwestern China: Geochimica, v. 21, p. 201-212.

Manuscript received August 9, 1996

Revised manuscript received December 2, 1996

Manuscript accepted December 10, 1996 